\title{
Diversification of the pectoral fin shape in damselfishes (Perciformes, Pomacentridae) of the Eastern Pacific
}

\author{
R. Aguilar-Medrano $\cdot$ B. Frédérich $\cdot$ \\ E. F. Balart $\cdot$ E. de Luna
}

Received: 24 April 2012/Revised: 11 October 2012/Accepted: 30 October 2012/Published online: 18 November 2012

(c) Springer-Verlag Berlin Heidelberg 2012

\begin{abstract}
Fin shape strongly influences performance of locomotion across all swimming styles. In this study, we focused on the diversity of the pectoral fin morphology in damselfishes of the Eastern Pacific. Underwater observations and a review of literature allowed the characterization of ten behavioral groups. Territorial and non-territorial species were discriminated easily with traditional morphometrics. Five ecomorphological groups were recognized by geometric morphometric analyses. Geometric data segregated the outgroup from the damselfishes and allowed the distinction of mean morphologies from extreme ones within territorial and non-territorial species. Additionally, geometric morphometric data split Abudefduf into two groups: (1) A. troschelii is similar to C. atrilobata and (2) A. concolor and A. declivifrons are close to Stegastes. Solitary territorial species (e.g., Stegastes) show rounded
\end{abstract}

Communicated by A. Schmidt-Rhaesa.

Electronic supplementary material The online version of this article (doi:10.1007/s00435-012-0178-8) contains supplementary material, which is available to authorized users.

R. Aguilar-Medrano $(\square) \cdot$ E. F. Balart

Laboratorio de Necton y Ecología de Arrecifes,

Centro de Investigaciones Biológicas del Noroeste,

La Paz, B.C.S., 23096 Mexico, Mexico

e-mail: liabiol@gmail.com

B. Frédérich

Laboratoire de Morphologie fonctionnelle et évolutive, Institut de Chimie (B6c), Université de Liège,

4000 Liège, Belgium

E. de Luna

Departamento de Biodiversidad y Sistemática, Instituto de Ecología, AC, 91000 Xalapa,

Veracruz, Mexico and high fins whereas non-territorial species living in groups (e.g., Chromis) present long and curved pectoral fins. In the range of morphological variation, the morphologies of Microspathodon (elongate with highly curved hydrodynamic trailing edge) and Azurina (long, slender and angular) represent the extreme morphologies within territorial and non-territorial species, respectively. Our study revealed a strong relationship between the pectoral fin shape and the behavioral diversification in damselfishes.

Keywords Ecomorphology · Geometric morphometrics · Locomotion · Reef fishes $\cdot$ Swimming $\cdot$ Territorial behavior

\section{Introduction}

Fish swimming gaits can be divided into two functional groups: (1) median-paired fin gaits (MPF) and (2) bodycaudal fin gaits (BCF). BCF swimming, the ancestral condition in vertebrates and the most common swimming style in fishes (Sfakiotakis et al. 1999; Lauder 2000), involves undulation of the body and caudal fin to create thrust. Conversely, some more derived groups of fishes (e.g., order Perciformes, suborder Labroidei) are specialized MPF swimmers for which gaits are powered by one or more median or paired fins, while the body is held rigid (Webb 1982; Sfakiotakis et al. 1999; Lauder and Liem 1983). MPF swimming is generally considered to provide greater maneuverability, stability at slow swimming speeds and is presumably advantageous for movements through structurally complex habitats, such as coral and rocky reefs (Webb 1982).

The two principal movements in MPF swimmers have been proposed: rowing and flapping (Walker and Weastneat 2002; Walker 2004). Rowing generates thrust at low 
speeds, while flapping generates more thrust at high speeds. Fishes that swim at high speeds using a flapping fin motion will tend to have elongated, tapered fins while fishes that swim slowly using a more horizontal stroke plane angle of fin are expected to have more symmetrical rounded fins (Wainwright et al. 2002). Pectoral fins play important roles by controlling body position and propelling during steady and unsteady swimming behaviors (Drucker and Lauder 2002; Lauder et al. 2002). Relatively low-speed swimming commonly involves the use of pectoral fins to generate locomotor forces and comprises most of time activity (Webb 2002).

The outstanding evolutionary radiation of bony fishes is characterized by a pronounced morphological diversification of the paired fins. Specifically, the greatest diversity of pectoral fin designs occurs among the Actinopterygii (Drucker and Lauder 2002). Within the Perciformes, clear intra-familiar variation has been observed in the shape of pectoral fin (Wainwright et al. 2002; Walker and Weastneat 2002).

Swimming performance and physical properties such as body and fin shapes are crucial factors for the adaptation of fishes to their environment. During the last 10 years, studies devoted to the ecomorphology of locomotion in reef fishes have accumulated evidence supporting the notion that complex three-dimensional structure of rocky and coral reefs shaped a lot of adaptations in teleosts during their evolution (Fulton et al. 2001; Fulton and Bellwood 2002; Wainwright et al. 2002; Walker and Weastneat 2002; Fulton 2007). The variation of fin shape was studied in various fish groups such as labrid and balistid fishes (e.g., Fulton 2007; Dornburg et al. 2011). Ecomorphological analyses revealed a strong relationship between habitat use and functional design of the fins in reef fishes (Fulton and Bellwood 2002; Wainwright and Bellwood 2002; Fulton 2007). The performance of pectoral fin locomotion is highly influenced by fin shape and orientation (Wainwright et al. 2002; Fulton et al. 2005).

With more than 380 species, the Pomacentridae (damselfishes) is a dominant perciform fish family of rocky and coral reefs (Allen 1975, 1991). They display remarkable diversity related to habitat preferences, feeding habits and behaviors (Robertson and Allen 2008). For example, some herbivorous damselfishes are highly territorial and manage their own algae farm (e.g., Stegastes) (Lobel 1980; Ceccarelli 2007) when several planktivorous damselfishes (e.g., Chromis, Abudefduf) are schooling species feeding in the water column (Emery 1973; Frédérich et al. 2009). All formerly studied damselfishes show pectoral fin swimming (MPF), except some species belonging to the genera Plectroglyphidodon, Dischistodus and Stegastes which use both pectoral and caudal fins for swimming (Fulton 2007).
Here, we focus on the pattern of diversification of the pectoral fins in damselfishes of the Eastern Pacific where 24 endemic species have been reported (Fig. 1; Robertson and Allen 2008). All genera represented in this region belong to the basal groups of the family Pomacentridae (i.e., the subfamilies Stegastinae, Chrominae and Abudefdufinae) as defined by Cooper et al. 2009 (Fig. 2). Damselfishes of the Eastern Pacific present a wide range of habitat preferences and behaviors from solitary and territorial to free swimmers forming groups.

The hypothesis involved testing whether ecological diversification is related to a morphological variation of pectoral fins in damselfishes. Thus, firstly habitat preferences and behavioral diversity in the 24 damselfish species are described. Secondly, traditional morphological descriptors (i.e., fin aspect ratio and angle of fin attachment; Fulton and Bellwood 2002; Wainwright and Bellwood 2002; Fulton 2007) and geometric morphometric methods (Adams et al. 2004) are used to explore the diversity of pectoral fin morphology. Finally, the relationship between shape variation and behavioral diversity was tested to determine lines of adaptive evolution in damselfishes of the Eastern Pacific.

\section{Materials and methods}

\section{Outgroup}

For the morphological and behavioral comparisons, the embiotocid Zalembius rosaceus (Jordan and Gilbert 1880) was included in all analyses as an outgroup. Embiotocidae is recognized as the sister group of Pomacentridae (Streelman and Karl 1997; Mabuchi et al. 2007). Zalembius rosaceus is distributed in the same geographical region of the studied damselfishes and inhabits rocky reefs and open trawl grounds, where damselfishes were never observed.

\section{Behavioral data}

In addition to an extensive review of the literature, the social behavior of fourteen damselfishes species was studied by underwater observations (UO) in three areas in the Gulf of California, Mexico (Table 1; Fig. 1), using the methodology as described in Aguilar-Medrano et al. (2011). During UO, the primary focus was on a selected number of traits related to territorial and non-territorial behavior. For territorial species, approximate size of the territory was determined and if they lived as couples or solitary. For non-territorial species, the approximate size of the group was determined or if they were solitary. Additionally, we registered the approximate positions of the fish in the column of water. We categorized damselfish within 


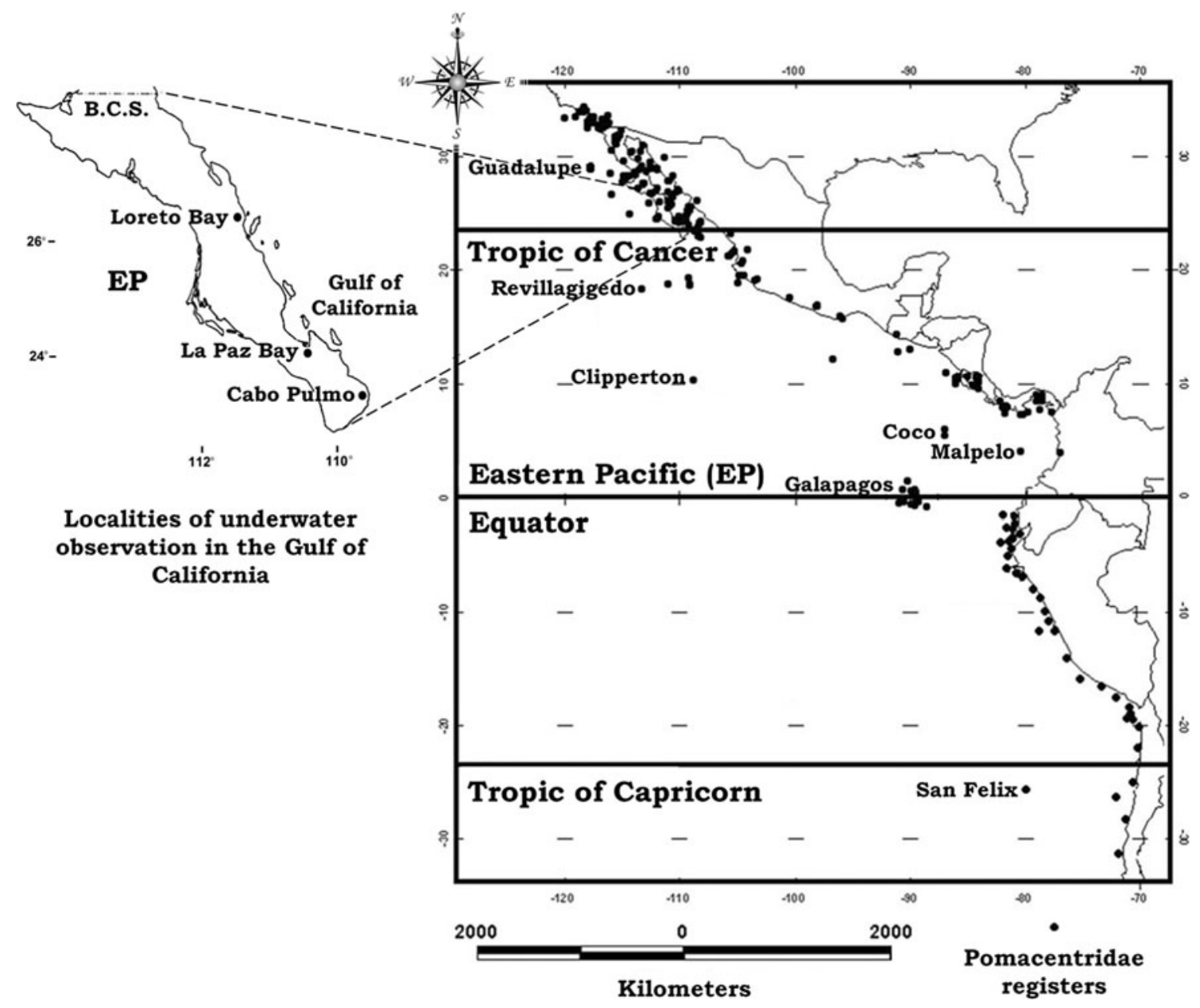

Fig. 1 Distribution of damselfishes in the Eastern Pacific coast and islands. Dots indicate locality records for Pomacentridae. In the left, localities of underwater observations in the Gulf of California:

the five groups defined by Hobson and Chess (1978) according to the distance from the reef and the position in the water column (Fig. 3). The five categories were adapted for the present analyses as shown below: (a) species living above the bottom rocks: (b) species living close to walls or rocks, but not over the bottom rocks; (c) species living close to the reef, swimming around, rarely observed near the surface; (d) species living from midwater and close to the surface; (e) species exposed to wave action. This last category relates to fishes in low shallow waters in rocky areas where the waves break (Fig. 3). A matrix of presence/absence of 12 categories describing the behavior (seven categories) and position in the water column (five categories) of the 24 endemic damselfishes and Z. rosaceus was built (Table 2). The behavioral data were summarized in a cluster analysis using an UPGMA algorithm, which allowed for determining various behavioral groups (see results). The goodness of fit of the cluster analysis was measured by the coefficient of cophenetic correlation (Cardini and Elton 2008).
National Marine Park of Loreto, La Paz Bay and National Marine Park of Cabo Pulmo

Fin morphometrics

A total of 246 specimens representing all 24 damselfish species of the Eastern Pacific were sampled (Table 1). The minimum representation was five specimens per species (one species) and the maximum was 20 . Some specimens were speared during field studies and others came from the collections at CIBNOR (La Paz, Mexico), CICIMAR (La Paz, Mexico), SIO (San Diego, CA, USA), LACM (Los Angeles, USA) and USNM (Washington, USA) (Table 1). The list of museum specimens used in this study is available as an online resource (Online Resource 1). Upon capture, fishes were preserved in neutralized and buffered $10 \%$ formalin for 10 days and then transferred to $80 \%$ alcohol. The standard length of each fish (SL, length from the tip of the snout to the posterior edge of the caudal peduncle) was measured to the nearest millimeter with a Vernier caliper. Left pectoral fin of all specimens was deployed to their maximum degree; fishes were photographed with digital camera (Kodak $4 \times$ optical and 4 Mega 
Fig. 2 Phylogenetic hypothesis of Cooper et al. (2009). Square: subfamily Chrominae; circle: subfamily Stegatinae; triangle: subfamily Abudefdufinae. Asterix: subfamilies not present in the Eastern Pacific Ocean. Numbers above branches are posterior probabilities of nodes. Numbers below branches are the MP bootstrap support values for branches that were identical in both the Bayesian and MP bootstrap analyses. Nexilosus latifrons present a thick line indicating the authors propose that this may be its position, but the analysis did not resolve its position

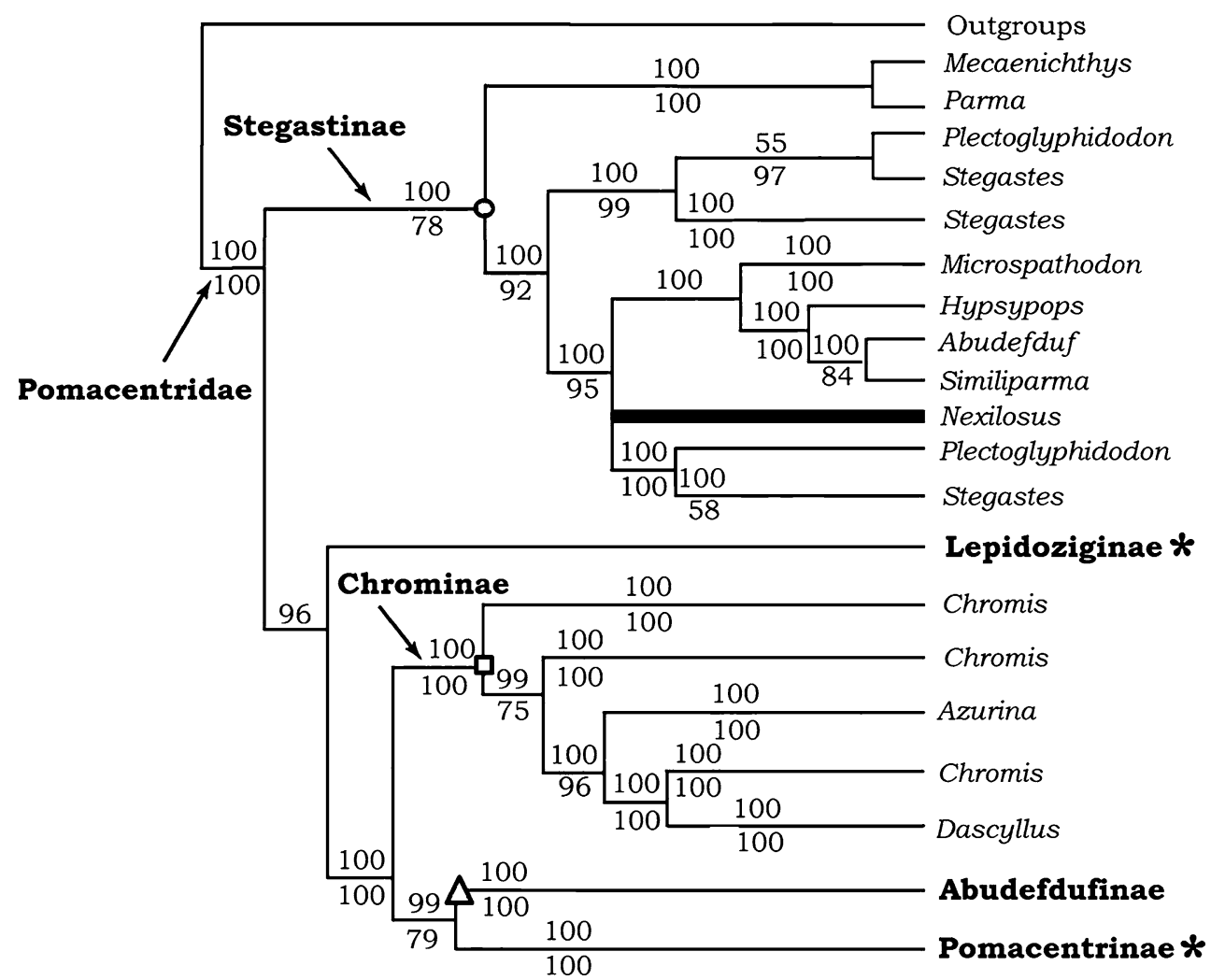

pixels) in a perfect lateral view. Broken or damaged fins were never considered in the present study. Most of the damselfishes of the Eastern Pacific are large species (Table 1). Hence, for specimens having complete but bent pectoral fins, the fin was splinted with toothpicks and left in water for 1 week to loosen the tissue and to comply with the standards required to be photographed.

We assessed the patterns of pectoral fin morphological variation using traditional and geometric morphometrics (GM). Firstly, each image was used to measure the length of the leading edge and the total fin area following Fulton et al. (2001) (Fig. 4). Fin morphology was expressed as a fin aspect ratio (AR), which was calculated as leading edge $^{2} /$ area $^{-1}$. The angle of fin attachment (AFA) was calculated taking a horizontal line from the middle of the body of each specimen. We measured the angle of fin attachment onto the body by first placing each fish on a sheet of polystyrene with its long axis oriented along a line drawn on the plastic, the pectoral fin was then elevated to a position approximately perpendicular to the surface of the body and a thread with pins at either end was positioned along the base of the fin to provide an orientation line of the fin base (Wainwright et al. 2002) (Fig. 4). Then, the shape and size of pectoral fin were quantified using GM (Bookstein 1991; Rohlf and Marcus 1993; Rohlf 1999; Zelditch et al. 2004). To capture as much fin shape variation as possible, five landmarks (LMs) and five semilandmarks (SLMs) (Monteiro et al. 2005) were recorded with the software TpsDig (Version 2.05). This configuration allows the representation of the three main components of the pectoral fin shape (Fig. 4): the angle of fin attachment determined by LMs 1 and 10; the hydrodynamic leading edge delimited by LMs 1-3; and the hydrodynamic trailing edge determined by LMs 3- 9 .

Configurations were optimally superimposed using a generalized procrustes analysis (GPA, Rohlf and Slice 1990; Rohlf 1999) to obtain a matrix of shape coordinates. This least squares procrustes superimposition aligned landmark configurations such that the sum of squared distances between corresponding landmarks was minimized with respect to the "grand mean" (consensus) shape, thus removing differences related to scaling, position and orientation. The partial warp scores (PWs) (Bookstein 1991; Rohlf 1993) were calculated through GPA using TpsRelw (Version 1.46). The PWs including both uniform and non-uniform components were used as shape variables for the statistical analyses. The geometric size of the pectoral fin was estimated by the centroid size (CS), defined as the square root of the sum of the squares of the distances from all landmarks to the centroid of the configuration (Bookstein 1991).

\section{Statistical analyses}

The Kolmogorov-Smirnov test was used to test the normality of the traditional morphometric data of pectoral fin 
Table 1 Sites of underwater observation in the Gulf of California, México

\begin{tabular}{|c|c|c|c|c|c|c|c|}
\hline Species & Loreto bay & La Paz bay & Cabo Pulmo & $n$ & n M & n CW & $\mathrm{SL}(\mathrm{cm})$ \\
\hline A. concolor (Gill 1862) & & & & 7 & 7 & 0 & 13 \\
\hline A. declivifrons (Gill 1862) & $\mathrm{X}$ & $\mathrm{X}$ & $\mathrm{X}$ & 7 & 0 & 7 & 13 \\
\hline A. troschelii (Gill 1862) & $\mathrm{X}$ & $\mathrm{X}$ & $\mathrm{X}$ & 10 & 8 & 2 & 13 \\
\hline A. eupalama Heller and Snodgrass 1903 & & & & 5 & 5 & 0 & 10 \\
\hline A. hirundo Jordan and McGregor in 1898 & & & & 8 & 8 & 0 & 13 \\
\hline C. alta Greenfield and Woods 1980 & $\mathrm{X}$ & $\mathrm{X}$ & $\mathrm{X}$ & 7 & 6 & 1 & 10 \\
\hline C. atrilobata Gill 1862 & $\mathrm{X}$ & $X$ & $\mathrm{X}$ & 15 & 4 & 11 & 8 \\
\hline C. crusma (Valenciennes in Cuvier and Valenciennes 1833) & & & & 10 & 10 & 0 & 13 \\
\hline C. intercrusma Evermann and Radcliffe 1917 & & & & 5 & 5 & 0 & 16 \\
\hline C. limbaughi Greenfield and Woods 1980 & $\mathrm{X}$ & & & 6 & 3 & 3 & 11 \\
\hline C. meridiana Greenfield and Woods 1980 & & & & 12 & 12 & 0 & 10 \\
\hline C. punctipinnis (Cooper 1863) & & & $\mathrm{X}$ & 11 & 11 & 0 & 19 \\
\hline H. rubicundus (Girard 1854) & & & $X$ & 12 & 6 & 6 & 20 \\
\hline M. bairdii (Gill 1862) & $\mathrm{X}$ & $X$ & $X$ & 9 & 4 & 5 & 21 \\
\hline M. dorsalis (Gill 1862) & $\mathrm{X}$ & $\mathrm{X}$ & $\mathrm{X}$ & 20 & 5 & 15 & 18 \\
\hline N. latifrons (Tschudi 1846) & & & & 7 & 7 & 0 & 22 \\
\hline S. acapulcoensis (Fowler 1944) & & $\mathrm{X}$ & $\mathrm{X}$ & 15 & 14 & 1 & 12 \\
\hline S. arcifrons (Heller and Snodgrass 1903) & & & & 10 & 10 & 0 & 11 \\
\hline S. baldwini Allen and Woods 1980 & & & & 3 & 3 & 0 & 8 \\
\hline S. beebei (Nichols 1924) & & & & 6 & 6 & 0 & 11 \\
\hline S. flavilatus (Gill 1862) & $\mathrm{X}$ & $\mathrm{X}$ & & 15 & 10 & 5 & 11 \\
\hline S. leucorus (Gilbert 1892) & $\mathrm{X}$ & $\mathrm{X}$ & $\mathrm{X}$ & 12 & 3 & 9 & 12 \\
\hline S. rectifraenum (Gill 1862) & $X$ & $\mathrm{X}$ & $\mathrm{X}$ & 10 & 0 & 10 & 10 \\
\hline S. redemptus (Heller and Snodgrass 1903) & & & $\mathrm{X}$ & 10 & 10 & 0 & 12 \\
\hline Z. rosaceus (Jordan and Gilbert 1880) & & & & 13 & 13 & 0 & 13 \\
\hline
\end{tabular}

$n$ number of specimens, $n M$ number of specimens from Museum collections, $n C W$ number of specimens collected in the wild, $S L$ standard length

Fig. 3 Categories of the position in the column water: (a) species living over the bottom rocks: (b) species living close to walls or rocks, but no over the bottom rocks;

(c) species living close to the reef, swimming around, rarely observed near the surface;

(d) species living from midwater to close to the surface; (e) species exposed to the wave action. (see Table 2)

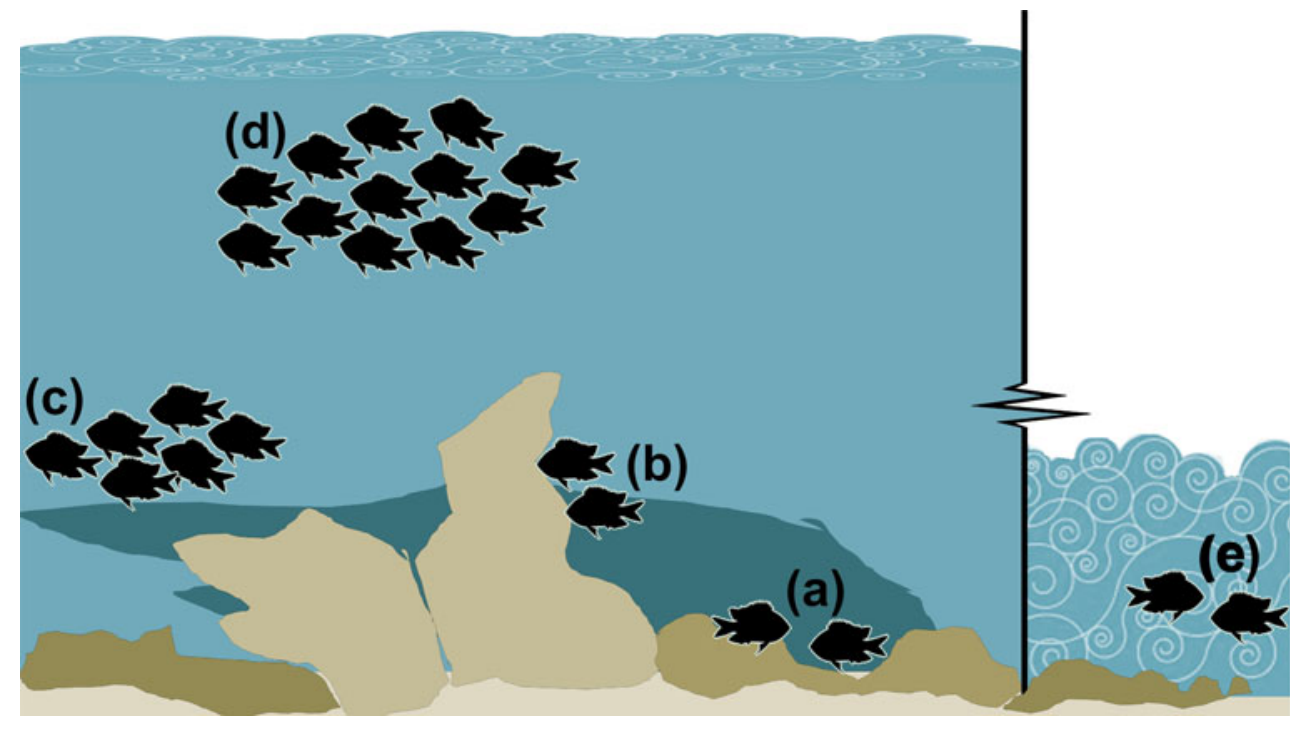

(i.e., AFA and AR). Nonparametric Kruskal-Wallis tests and Dunn's post hoc tests were used to compare both traits among species and behavioral groups. Correlation analyses were used to test (1) a hypothetical linear relationship between these two morphological parameters through all studied species and (2) a hypothetical relationship between fish size (SL) and both morphological characters. Wainwright et al. (2002) measured AFA and AR in 143 species 
Table 2 Position in the water column and behavior of Pomacentridae family and Zalembius rosaceus in the Eastern Pacific

\begin{tabular}{|c|c|c|c|c|c|c|c|c|c|c|c|c|c|}
\hline \multirow[t]{3}{*}{ Species } & \multicolumn{7}{|c|}{ Behavior } & \multirow{2}{*}{\multicolumn{5}{|c|}{ Position in the water column }} & \multirow[t]{3}{*}{ Author } \\
\hline & \multicolumn{4}{|c|}{ PT } & \multicolumn{3}{|c|}{ TORS } & & & & & & \\
\hline & A & $\mathrm{B}$ & $\mathrm{C}$ & $\mathrm{D}$ & $\mathrm{E}$ & $\mathrm{F}$ & $\mathrm{G}$ & $\mathrm{a}$ & $\mathrm{b}$ & $\mathrm{c}$ & $\mathrm{d}$ & e & \\
\hline A. concolor & 0 & 0 & 0 & 0 & 0 & 1 & 1 & 1 & 0 & 0 & 0 & 1 & Robertson and Allen (2008) \\
\hline A. declivifrons & 0 & 0 & 0 & 0 & 0 & 1 & 1 & 1 & 0 & 0 & 0 & 1 & UO; Robertson and Allen (2008) \\
\hline A. troschelii & 0 & 0 & 0 & 0 & 1 & 0 & 0 & 1 & 1 & 1 & 1 & 0 & $\begin{array}{l}\text { UO; Hobson (1965), Grove and Lavenberg (1997), } \\
\text { Petersen and Marchetti (1989), Robertson and Allen (2008) }\end{array}$ \\
\hline A. eupalama & 0 & 0 & 0 & 0 & 1 & 0 & 0 & 1 & 1 & 1 & 0 & 0 & Robertson and Allen (2008) \\
\hline A. hirundo & 0 & 0 & 0 & 0 & 1 & 0 & 0 & 1 & 1 & 1 & 0 & 0 & Robertson and Allen (2008) \\
\hline C. alta & 0 & 0 & 0 & 0 & 0 & 1 & 0 & 1 & 1 & 0 & 0 & 0 & Robertson and Allen (2008) \\
\hline C. atrilobata & 0 & 0 & 0 & 0 & 1 & 0 & 0 & 0 & 1 & 1 & 1 & 0 & $\begin{array}{l}\text { UO; Hobson (1965), Espinoza and Salas (2005), } \\
\text { Robertson and Allen (2008) }\end{array}$ \\
\hline C. crusma & 0 & 0 & 0 & 0 & 0 & 1 & 0 & 1 & 1 & 1 & 0 & 0 & Núñez and Vásquez (1987), Angel and Ojeda (2001) \\
\hline C. intercrusma & 0 & 0 & 0 & 0 & 0 & 1 & 0 & 1 & 1 & 1 & 0 & 0 & Robertson and Allen (2008) \\
\hline C. limbaughi & 0 & 0 & 0 & 0 & 0 & 1 & 0 & 1 & 1 & 0 & 0 & 0 & UO; Robertson and Allen (2008) \\
\hline C. meridiana & 0 & 0 & 0 & 0 & 0 & 1 & 0 & 1 & 1 & 0 & 0 & 0 & Pequeño, pers. comm. \\
\hline C. punctipinnis & 0 & 0 & 0 & 0 & 0 & 1 & 0 & 1 & 1 & 1 & 0 & 0 & Rothans and Miller (1991), Bray et al. (1988) \\
\hline H. rubicundus & 0 & 1 & 1 & 0 & 0 & 0 & 0 & 1 & 1 & 1 & 1 & 1 & Hixon (1981), Robertson and Allen (2008) \\
\hline M. bairdii & 1 & 0 & 1 & 1 & 0 & 0 & 0 & 1 & 1 & 1 & 0 & 0 & UO; Robertson and Allen (2008) \\
\hline M. dorsalis & 1 & 0 & 1 & 1 & 0 & 0 & 0 & 1 & 1 & 1 & 0 & 0 & UO; Espinoza and Salas (2005), Robertson and Allen 2008 \\
\hline N. latifrons & 0 & 0 & 0 & 0 & 0 & 1 & 0 & 1 & 0 & 0 & 0 & 1 & $\begin{array}{l}\text { Grove and Lavenberg (1997), Angel and Ojeda (2001), } \\
\text { Robertson and Allen (2008) }\end{array}$ \\
\hline S. acapulcoensis & 0 & 1 & 1 & 0 & 0 & 0 & 0 & 1 & 0 & 0 & 0 & 0 & UO; Espinoza and Salas (2005), Robertson and Allen (2008) \\
\hline S. arcifrons & 0 & 1 & 1 & 0 & 0 & 0 & 0 & 1 & 0 & 0 & 0 & 0 & Grove and Lavenberg (1997), Robertson and Allen (2008) \\
\hline S. baldwini & 0 & 1 & 1 & 0 & 0 & 0 & 0 & 1 & 0 & 0 & 0 & 0 & Robertson and Allen (2008) \\
\hline S. beebei & 0 & 1 & 1 & 0 & 0 & 0 & 0 & 1 & 0 & 0 & 0 & 0 & Grove and Lavenberg (1997), Robertson and Allen (2008) \\
\hline S. flavilatus & 0 & 1 & 1 & 0 & 0 & 0 & 0 & 1 & 0 & 0 & 0 & 0 & $\begin{array}{l}\text { UO; Petersen and Marchetti (1989), Espinoza and Salas (2005), } \\
\text { Robertson and Allen (2008) }\end{array}$ \\
\hline S. leucorus & 0 & 1 & 1 & 0 & 0 & 0 & 0 & 1 & 0 & 0 & 0 & 0 & UO; Robertson and Allen (2008) \\
\hline S. rectifraenum & 0 & 1 & 1 & 0 & 0 & 0 & 0 & 1 & 0 & 0 & 0 & 0 & $\begin{array}{l}\text { UO; Hobson (1965), Petersen and Marchetti (1989), } \\
\text { Robertson and Allen (2008) }\end{array}$ \\
\hline S. redemptus & 0 & 1 & 1 & 0 & 0 & 0 & 0 & 1 & 0 & 0 & 0 & 0 & Robertson and Allen (2008) \\
\hline Z. rosaceus & 0 & 0 & 1 & 0 & 0 & 1 & 0 & 1 & 1 & 1 & 0 & 0 & Robertson and Allen (2008) \\
\hline
\end{tabular}

Behavior: PT perennial territorial: (A) protect big territories ( $<1 \mathrm{~m}$ high); (B) protect small territories ( $>1 \mathrm{~m}$ high); (C) solitary; (D) live in pairs; TORS territorials only during reproductive season: (E) big groups ( $<30$ fishes); (F) small groups ( $>30$ fishes); (G) can be found solitary. Position in the water column: (a) bottom: (b) close to the bottom; (c) midwater; (d) close to the surface; (e) exposed to the wave action. $U O$ underwater observations

of labrid fishes from the Great Barrier Reef and the Caribbean. In those fishes, variation of AFA and AR was highly correlated $\left(r^{2}=-0.65, P<0.05\right.$; Wainwright et al. 2002). As both variables are also correlated in damselfishes (see results), an ANCOVA was used to test the null hypothesis that the linear model is identical between the two families.

A principal components analysis (PCA) was performed on GM variables (PWs) to explore the main axes of pectoral fin shape variation among 247 specimens using TpsRelw.

As a statistical test for the presence of overall differences among species and behavioral groups, we used one- way MANOVAs. When the MANOVA revealed significant differences among groups, pairwise multiple comparisons using Hotelling's $\mathrm{T}$ value with uncorrected significance and sequential Bonferroni significance were performed to determine which group differed from one another. Canonical variables analyses (CVA) were used to assess the shape variation among groups. To display the shape features associated with PC and CV axes, we used thin-plate spline algorithm (Bookstein 1991) to produce transformation grids representing extreme positive and negative deviations along the axis. Finally, the patterns of shape variation related to size were compared across species with a multivariate regression of shape variables 
Fig. 4 Pectoral fin showing (a) angle of fin attachment and (b) five landmarks (LMs 1-3, 9, 10) and five semilandmarks (SLMs 4-8) considered in the analysis, grouped into three main axes of form: (1) angle of fin attachment (LMs 1 and 10); (2) hydrodynamic leading edge (LMs 1-3); (3) hydrodynamic trailing edge (LMs 3-9). LM1: up origin of the pectoral fin; LM2: end of the spine of the pectoral fin; LM3: upper maximum length; SLMs 4-8: semilandmarks between the upper maximum length and the lower minimum length; LM9: lower minimum length; LM10: down origin of the pectoral fin
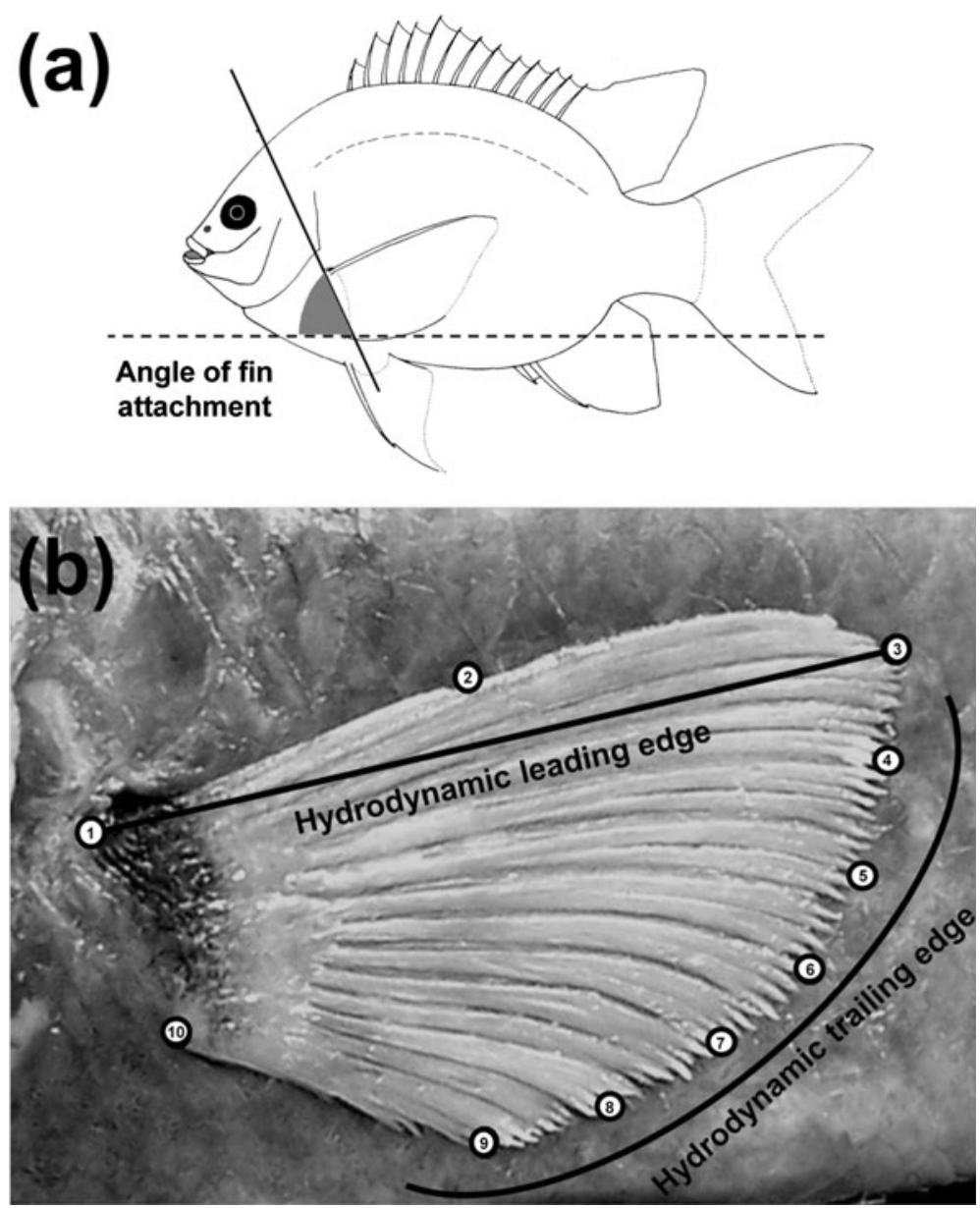

(PWs) onto CS, using the mean CS and configuration of each species (TpsRegr, Version 1.28) (Monteiro 1999).

Cluster analysis was performed to determine the morphological relationship of the species without the phylogenetic signal. We used Mahalanobis distances as measure of the similarity among species (Klingenberg and Monteiro 2005). The cluster was calculated using the unweighted pairgroup method algorithm (UPGMA). The goodness of fit of the cluster analysis was measured by the coefficient of cophenetic correlation.

Univariate and multivariate analyses (Kruskal-Wallis tests, ANCOVA, PCA, CVA, MANOVA, clustering) were computed with the statistical packages: PAST 2.16 (Hammer et al. 2001, freely available at: http://folk.uio. no/ahammer/past), Statistica 8.0 StatSoft.com and JMP 8.0 SAS Institute Inc.

\section{Results}

Behavioral groups

The UPGMA analysis reveals ten behavioral groups (Coph. Corr. $=0.966$; Fig. 5). The two main clusters were found to be territorial and non-territorial species (Fig. 5). Territorial species (Stegastes, Microspathodon and H. rubicundus) were segregated between solitary and couples. Non-territorial species as Abudefduf, Azurina, Chromis, $N$. latifrons and Z. rosaceus were segregated according to group size and position in the water column. This analysis highlighted two behavioral convergences: A. troschelii was recovered into Chrominae, while $N$. latifrons belonged to Stegastinae was recovered into Abudefdufinae.

Territorial species such as Stegastes, Microspathodon and $H$. rubicundus generally swim around their territory, staying close to the substrate. When an intruder approaches their territory, these fishes typically chase the intruder and return to their territory. During day time, they commonly cultivate and eat algae in their territory. These species show a suite of behavior and territory preferences. The most specific are Stegastes which are solitary species selecting small rocks or coral on the bottom of rubble areas as territories. Microspathodon live in couples or are solitary, at the bottom of the reef to midwater, while swimming around its territory, above the rocky reef or sandy areas crossing from one patch reef to another. The territory occupied by Microspathodon generally includes large rocks with high vertical walls. Hypsypops rubicundus is a 
Fig. 5 UPGMA phenogram for the social behavior data and position in the column water. Letters $a$ to $e$ refers to position in the column water, see Fig. 2, Table 2. G: could be founded solitary, also, is main social behavior is to form groups. Coefficient of cophenetic correlation $=0.966$

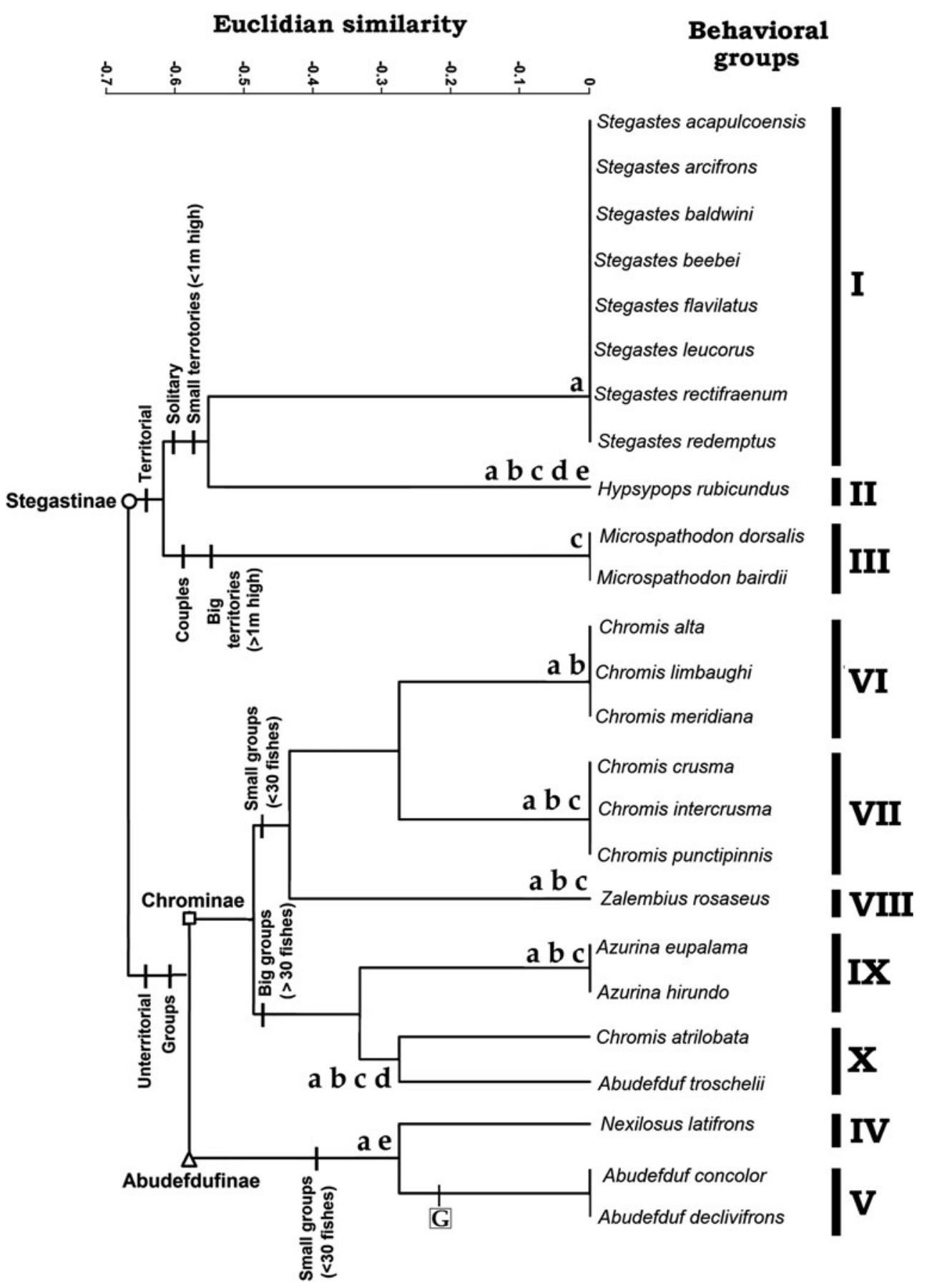

solitary species that can be found in all parts of the water column. It is found distributed in the rocky reef and kelp forest exposed to wave action. Generally, its territory is typically a small cave in big rocks. Among this first group of territorial species, no variation in the behavioral pattern was observed at the intra-generic level.

Except for their reproductive season, Abudefduf,Azurina and Chromis generally swim in the water column close to the rocky reef feeding mainly on zooplankton. They form aggregations (i.e., schooling species) constantly moving around the reefs. They present intra-generic variation in their behavior and habitat preferences. Abudefduf can be divided into two groups: (1) A. troschelii inhabits the water column, from the bottom to close to the surface and forms big groups swimming around the reefs; (2) A. concolor and A. declivifrons inhabit in the vicinity of the coastline, close to the bottom in the rocky reef and sandy areas exposed to the wave action. Chromis can be segregated into three groups according to group size and position in the water column: (1) C. atrilobata forms big groups $(>30$ 
individuals per group) and can be found swimming around the reefs, close to the bottom but more commonly close to the surface. The other two groups form smaller groups than C. atrilobata. (2) Chromis crusma, C. intercrusma and C. punctipinnis are distributed from the bottom to middle water and form mean groups ( $<30$ individuals per group). They inhabit rocky areas and kelp forests exposed to the wave action. (3) Chromis alta, C. limbaughi and C. meridiana are mainly found close to the bottom to middle water in rocky reefs. Azurina are generally found close to rocky habitats in open water, from the bottom to the middle water forming big groups (>30 individuals per group). Nexilosus latifrons can be considered as an intermediate group between free swimmers and territorial species because it normally forms small aggregations inhabiting close to the bottom and swims never far from its refuge (Grove et al. 1986). All damselfishes are static and hidden in caves or close to their territory during the night.

Morphological variation of the pectoral fin

\section{Traditional morphometrics}

In damselfishes of the Eastern Pacific, the AR ranged from 2.09 (S. arcifrons and S. rectifraenum) to 3.91 (A. hirundo) (Fig. 6a). The angle of fin attachment (AFA) varied from $57.3^{\circ}$ (A. hirundo) to $81.12^{\circ}$ (S. redemptus) (Fig. 6b). The Embiotocid Z. rosaceus showed a mean value of AR (3.12) included in the range of damselfishes, but it had the lowest value of AFA $\left(43.9^{\circ}\right)$. The Kruskal-Wallis tests revealed significant differences among species for the AR $\left(H_{24,247}=\right.$ $174.1 ; P<0.01)$ and AFA $\left(H_{24}, 247=188.5 ; P<0.01\right)$ values. According to the variation of AFA and AR, Dunn's post hoc tests allowed the discrimination of four groups (Fig. 6).

Stegastes, H. rubicundus and N. latifrons showed the lowest AR values (Fig. 6a). Microspathodon were grouped with Chromis and showed higher AR values than territorial species. The zooplanktivorous A. hirundo had the highest AR. Abudefduf, A. eupalama and Z. rosaceus formed an intermediate group between A. hirundo and all Chromis and Microspathodon (Fig. 6a). The AFA of Z. rosaceus is the most horizontal (Fig. 6b) followed by a group formed by all Abudefduf and Azurina. Conversely, H. rubicundus, N. latifrons and Stegastes showed the most vertical AFA (from $61.569^{\circ}$ to $81.12^{\circ}$, Fig. 6b). Microspathodon and Chromis formed a last group showing intermediate AFA values.

In a second step, we performed anew the KruskalWallis tests using behavior as grouping factor and significant differences were highlighted for AFA and AR values. According to AFA values $\left(H_{9}, 243=70.15 ; P<0.01\right)$, only three groups can be formed: (1) Stegastes,
H. rubicundus and N. latifrons, (2) Abudefduf, Azurina, Chromis and Microspathodon, and (3) Z. rosaceus. The variation of $\mathrm{AR}$ values $\left(H_{9,243}=46.30 ; P<0.01\right)$ allows the discrimination of four groups: (1) Stegastes, H. rubicundus and N. latifrons, (2) Z. rosaceus, Abudefduf and Chromis, (3) Azurina, and (4) Microspathodon (Table 3).

The variation of AR and AFA was not related to fish size, but the correlation between AFA and AR was high and significant within damselfishes (Table 4). Interestingly, the ANCOVA revealed that the covariation between AFA and AR is identical between damselfishes and labrids (test of common slopes: $F_{1,163}=3.103, P=0.08$ ). However, damselfishes seem to show higher mean values of AFA than labrids (homogeneity of intercepts: $F_{1,164}=198.604$, $P<0.001)$.

\section{Geometric morphometrics}

The main shape variation of pectoral fin among all specimens can be explored in the morphospace defined by PC1 and PC2 which accounted for $67 \%$ of the total shape variance (Fig. 7). The variation along PC1 distinguishes free swimmers such as Azurina and Chromis (-PC1), showing lengthened and slender fins, from mainly territorial species such as $H$. rubicundus and Stegastes and nonterritorial as $N$. latifrons $(+\mathrm{PC} 1)$, having short and high fins. Microspathodon and Abudefduf showed intermediate shapes. PC2 allows the segregation of $Z$. rosaceus from damselfishes (Fig. 7). Indeed, Z. rosaceus (+PC2) presents a relatively longer and straighter hydrodynamic leading edge and a relatively straighter hydrodynamic trailing edge than damselfishes. Additionally, the anterior part of its pectoral fin (LMs 1, 2 and 10,9) is shorter than in damselfishes. The hydrodynamic trailing edge of damselfishes is curved showing in the upper part of the pectoral fin an extension and in the down part a compression (-PC2, Fig. 7).

First, a MANOVA was performed using species as grouping factor. Our results revealed significant differences (Wilks'lambda 384, 2,846 $=0.00025, P<0.0001$; Pillai's trace $384,3,584=4.752, P<0.0001$ ), but due to the big shape difference between Pomacentridae and Z. rosaceus, the variation within Pomacentridae could not be adequately appreciated. So we performed a second MANOVA using behavior as grouping factor, this test revealed five morphological groups: (1) Stegastes, H. rubicundus, N. latifrons, A. concolor and A. declivifrons; (2) Microspathodon; (3) Chromis and A. troschelii; (4) Azurina; and (5) Z. rosaceus (Table 3). CVA was performed using the ten behavioral groups as grouping factor. The two first CVs summarize $79 \%$ of the total shape variance and strengthen the results of PCA analysis. CV1 highlights shape differences between $Z$. rosaceus and all damselfishes (Fig. 8). 
(a)

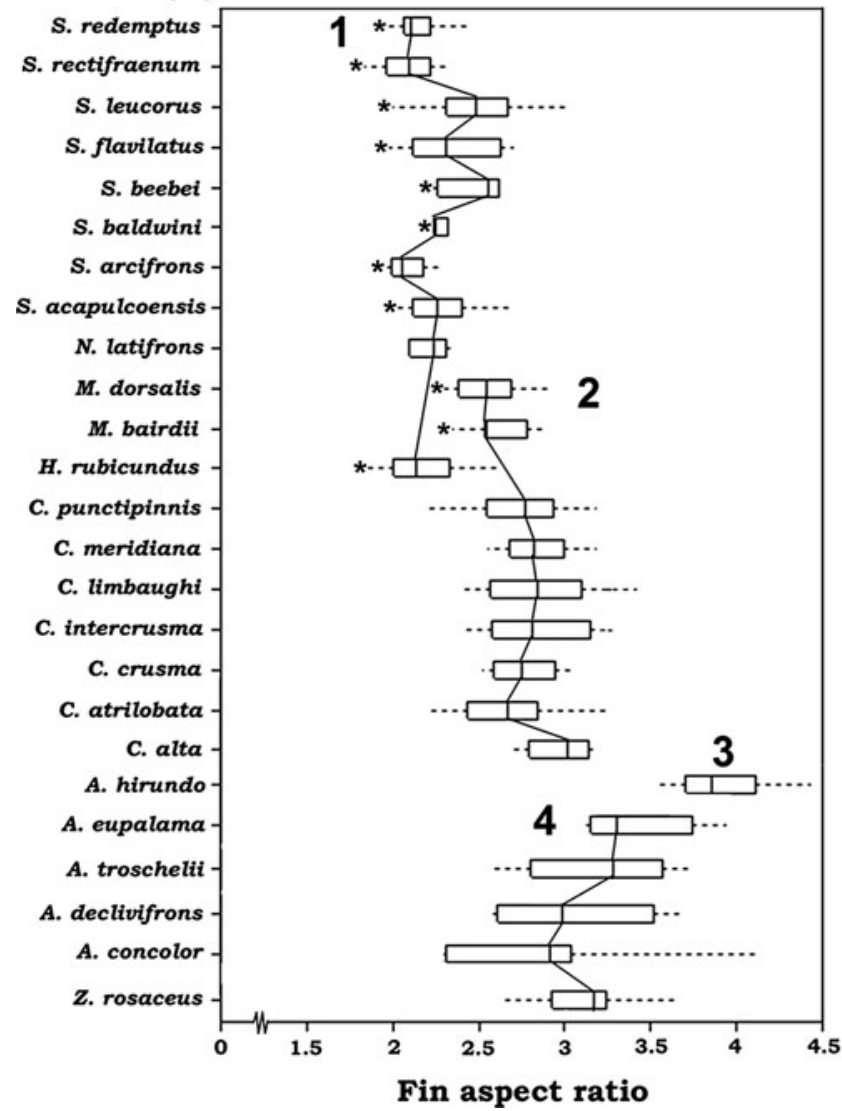

(b)

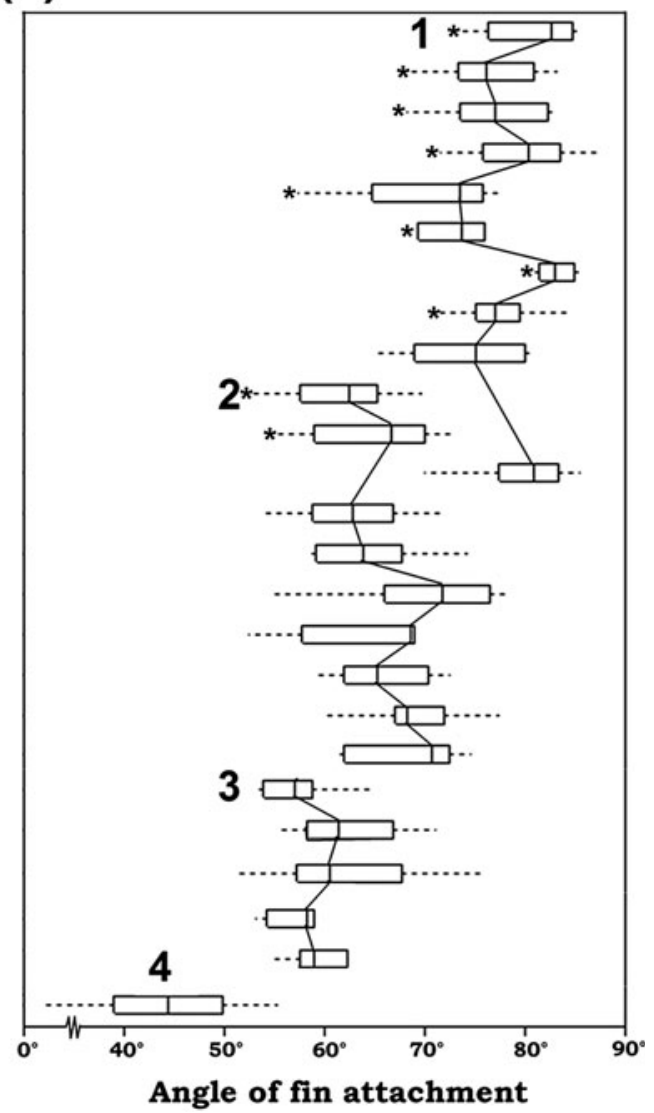

Fig. 6 Box-plot (median, percentiles 25 and $75 \%$, max and min) of (a) the pectoral fin aspect ratio and (b) the angle of fin attachment in all studied damselfishes and the outgroup. The homogeneous groups

Zalembius rosaceus (-CV1) has a slender and angular pectoral fin with long straight hydrodynamic leading edge and the anterior part of the fin is short, while damselfishes $(+\mathrm{CV} 1)$ show higher and more rounded pectoral fin. Along $\mathrm{CV} 2$, we observed a pattern of variation from free swimmers (Azurina, A. troschelii and C. atrilobata; +CV2), to mainly territorial species (Stegastes, H. rubicundus and N. latifrons; -CV2), which Microspathodon, Chromis, A. concolor and A. declivifrons have medium values of CV2. Free swimmers $(+\mathrm{CV} 2)$ present lengthened and slender fins, a long and almost straight hydrodynamic leading edge, short down support of the fin (LMs 9 and 10), low angle of fin attachment and rounded hydrodynamic trailing edge. Territorial species (-CV2) have high and short pectoral fins while Microspathodon have intermediated values, that is, longer and higher pectoral fins (Fig. 8).

Due to the large differences between $Z$. rosaceus and Pomacentrids, the UPGMA analysis puts $Z$. rosaceus in a sister group of all other taxa (Fig. 9). The values of the coefficient of cophenetic correlation (0.861) indicated a good fit of the variables to the cluster. Abudefduf appear together and apart from Chromis or Stegastes. Stegastes, revealed by ANOVA and post hoc test are linked in the mean value by straight lines. Asterisk: territorial species

$N$. latifrons and H. rubicundus form a group closely related to Chromis. The Chromis group did not include Azurina, but it includes Microspathodon.

\section{Discussion}

The damselfishes show a great diversity of pectoral fin shapes, from wing to paddle shape and intermediate morphologies. Most ecomorphological studies in Pomacentridae focused on the relationship between cephalic shape and feeding behavior (Gluckmann and Vandewalle 1998; Frédérich et al. 2008; Cooper and Weastneat 2009; Aguilar-Medrano et al. 2011; Frédérich and Vandewalle 2011). According to our results, locomotion can be viewed also as an important factor in the adaptive evolution of this group.

Ecomorphology

In their study of Labridae, Wainwright et al. (2002) found that high AR values are associated with low AFA values and vice versa. The same relationship was found in 
Table 3 Pairwise comparisons of shape variables (GM, AR, AFA) with behavior as grouping factor

\begin{tabular}{|c|c|c|c|c|c|c|c|c|c|c|}
\hline & I & II & III & IV & V & VI & VII & VIII & IX & $X$ \\
\hline \multicolumn{11}{|l|}{$A R$} \\
\hline I & 0 & 1.865 & 29.770 & 1.292 & 60.455 & 98.227 & 72.095 & 121.046 & 308.837 & 74.513 \\
\hline II & 0.175 & 0 & 24.433 & 0.004 & 23.784 & 68.103 & 48.974 & 89.463 & 148.053 & 28.068 \\
\hline III & $<.001$ & $<.001$ & 0 & 16.738 & 11.295 & 19.574 & 8.473 & 42.428 & 137.447 & 10.354 \\
\hline IV & 0.258 & 0.948 & $<.001$ & 0 & 14.846 & 47.228 & 33.434 & 64.027 & 98.841 & 17.518 \\
\hline $\mathrm{V}$ & $<.001$ & $<.001$ & 0.001 & 0.001 & 0 & 0.415 & 2.428 & 0.975 & 18.098 & 0.322 \\
\hline VI & $<.001$ & $<.001$ & $<.001$ & $<.001$ & 0.523 & 0 & 2.243 & 7.293 & 61.992 & 0.002 \\
\hline VII & $<.001$ & $<.001$ & 0.005 & $<.001$ & 0.127 & 0.141 & 0 & 15.732 & 83.712 & 1.092 \\
\hline VIII & $<.001$ & $<.001$ & $<.001$ & $<.001$ & 0.332 & 0.010 & $<.001$ & 0 & 20.607 & 3.546 \\
\hline IX & $<.001$ & $<.001$ & $<.001$ & $<.001$ & $<.001$ & $<.001$ & $<.001$ & $<.001$ & 0 & 35.159 \\
\hline $\mathrm{X}$ & $<.001$ & $<.001$ & 0.002 & $<.001$ & 0.573 & 0.961 & 0.301 & 0.067 & $<.001$ & 0 \\
\hline \multicolumn{11}{|l|}{$A F A$} \\
\hline I & 0 & 1.043 & 170.071 & 3.473 & 147.727 & 63.922 & 117.977 & 399.173 & 135.925 & 76.703 \\
\hline II & 0.309 & 0 & 89.769 & 6.021 & 131.194 & 35.399 & 69.906 & 226.646 & 118.478 & 36.957 \\
\hline III & $<.001$ & $<.001$ & 0 & 23.152 & 3.846 & 6.957 & 1.510 & 82.743 & 3.433 & 4.990 \\
\hline IV & 0.065 & 0.025 & $<.001$ & 0 & 39.258 & 6.137 & 15.861 & 91.129 & 35.314 & 6.982 \\
\hline $\mathrm{V}$ & $<.001$ & $<.001$ & 0.056 & $<.001$ & 0 & 15.110 & 8.955 & 42.624 & 6.001 & 11.946 \\
\hline VI & $<.001$ & $<.001$ & 0.011 & 0.019 & $<.001$ & 0 & 2.214 & 93.940 & 13.716 & 0.122 \\
\hline VII & $<.001$ & $<.001$ & 0.224 & $<.001$ & 0.004 & 0.143 & 0 & 94.867 & 8.068 & 1.193 \\
\hline VIII & $<.001$ & $<.001$ & $<.001$ & $<.001$ & $<.001$ & $<.001$ & $<.001$ & 0 & 39.292 & 86.884 \\
\hline IX & $<.001$ & $<.001$ & 0.071 & $<.001$ & 0.978 & $<.001$ & 0.007 & $<.001$ & 0 & 10.848 \\
\hline$X$ & $<.001$ & $<.001$ & 0.029 & 0.013 & $<.001$ & 0.727 & 0.280 & $<.001$ & 0.002 & 0 \\
\hline \multicolumn{11}{|l|}{$G M$} \\
\hline I & 0 & 2.394 & 15.242 & 5.843 & 43.993 & 10.450 & 11.466 & 147.735 & 39.122 & 16.005 \\
\hline II & 0.215 & 0 & 10.550 & 5.047 & 36.645 & 11.890 & 10.311 & 135.047 & 44.309 & 17.205 \\
\hline III & $<.001$ & 0.003 & 0 & 11.504 & 43.696 & 20.579 & 17.405 & 127.095 & 43.094 & 24.054 \\
\hline IV & 0.029 & 0.989 & 0.045 & 0 & 53.692 & 21.261 & 19.476 & 141.559 & 54.718 & 27.074 \\
\hline $\mathrm{V}$ & $<.001$ & 0.006 & $<.001$ & 0.128 & 0 & 28.460 & 24.223 & 154.055 & 40.819 & 23.112 \\
\hline VI & $<.001$ & 0.005 & $<.001$ & 0.008 & $<.001$ & 0 & 1.732 & 119.484 & 15.728 & 2.5467 \\
\hline VII & $<.001$ & 0.008 & $<.001$ & 0.008 & $<.001$ & 0.519 & 0 & 105.561 & 18.399 & 2.292 \\
\hline VIII & $<.001$ & $<.001$ & $<.001$ & 0.024 & $<.001$ & $<.001$ & $<.001$ & 0 & 152.42 & 122.965 \\
\hline IX & $<.001$ & $<.001$ & $<.001$ & 0.031 & $<.001$ & $<.001$ & $<.001$ & $<.001$ & 0 & 9.717 \\
\hline$X$ & $<.001$ & $<.001$ & $<.001$ & 0.002 & $<.001$ & 0.217 & 0.272 & $<.001$ & 0.002 & 0 \\
\hline
\end{tabular}

Above the diagonal $F$ values. Below the diagonal $P$ values. I all Stegastes species; II $H$. rubicundus; III both Microspathodon species; IV N. latifrons; V A. concolor, A. declivifrons; VI C. alta, C. limbaughi, C. meridiana; VII C. crusma, C. intercrusma, C. punctipinnis; VIII Z. rosaceus; IX both Azurina species; X.A. troschelii, C. atrilobata

Pomacentridae, and this pattern could be considered to be a general pattern in two of the most successful families of coral reef fishes.

Using traditional morphometrics (i.e., AR and AFA), it was possible to clearly discriminate four groups. Empirical data showed that species with low AR and high AFA swing the fin in front to back movements, as observed in rowing behavior, while species with high AR and low AFA swing the fin dorso-ventrally, as seen in flapping behavior (Walker and Weastneat 2002). Territorial damselfish species differ highly from non-territorial ones. Highly territorial damselfishes during all seasons such as Stegastes and
H. rubicundus have pectoral fins with low $\mathrm{AR}$ and high AFA. Their pectoral fins are relatively rounded (low AR) giving force and maneuverability, and a high AFA facilitates back and front movements in a horizontal sense. It was found that fishes with mainly free swimming behavior, such as Chromis, Abudefduf and A. eupalama, show fins with low AFA and high AR. Such morphology decreases the resistance to the water. A short and low support of the pectoral fin offers force and resistance, and a low AFA facilitates long movements in vertical sense.

Azurina hirundo and Z. rosaceus differ from other free swimmers by an extremely high AR and AFA, respectively 
Table 4 Regression analysis for testing interspecific allometry, morphometric and behavioral variables

\begin{tabular}{llrlr}
\hline Variables & $r^{2}$ & \multicolumn{1}{l}{$F$} & $d f$ & \multicolumn{1}{l}{$P$} \\
\hline CS versus AFA & 0.018 & 4.588 & $1 / 248$ & 0.033 \\
CS versus AR & 0.001 & 0.342 & $1 / 248$ & 0.559 \\
CS versus GM & 0.061 & 0.264 & $16 / 3,904$ & 0.608 \\
CS versus BD & 0.003 & 0.781 & $1 / 248$ & 0.378 \\
AFA versus AR & 0.612 & 389.176 & $1 / 248$ & $<0.001$ \\
AFA versus GM & 0.562 & 316.248 & $16 / 3,904$ & $<0.001$ \\
AFA versus BD & 0.430 & 186.218 & $1 / 248$ & $<0.001$ \\
AR versus GM & 0.474 & 223.148 & $16 / 3,904$ & $<0.001$ \\
AR versus BD & 0.558 & 311.212 & $1 / 248$ & $<0.001$ \\
GM versus BD & 0.454 & 209.942 & $16 / 3,904$ & $<0.001$ \\
\hline
\end{tabular}

$C S$ centroid size, $A F A$ angle of fin attachment, $A R$ fin aspect ratio, $B D$ behavior data, $G M$ geometric morphometric data (RWs)

(Fig. 6). AFA values show a clear difference between territorial and non-territorial damselfishes. Interestingly, Microspathodon, defending bigger territories, showed similar AFA values with non-territorial species. The geometric data allow a more in depth analysis of the morphological variation, allowing for the discrimination of five groups (Table 3; Fig. 9). The five ecomorphological groups are: (1) Stegastes, H. rubicundus, N. latifrons, A. concolor and A. declivifrons; (2) Microspathodon; (3)
Chromis and A. troschelii; (4) Azurina; and (5) the outgroup $Z$. rosaceus. In other words, these geometric data segregated the outgroup from the damselfishes and distinguished mean morphologies from extreme ones within territorial and non-territorial species.

Adults of $H$. rubicundus and Stegastes are highly territorial and farmers. This behavior requires a high level of precision as well as power in their swimming movements to keep out intruders and to guard their feeding area where they cultivate filamentous algae. This functional group shows high rounded pectoral fins, wide in the tip and the base. The first part of the fin (LMs 1-2 and 10-9; Fig. 4b) is short and high, providing a strong support for short movements. An angular hydrodynamic leading edge and the presence of a strongly curved hydrodynamic trailing edge allow movements with high precision. Theoretical results suggest that a paddling mechanism is best suited for this fin morphology (Blake 1981; Weastneat and Walker 1997; Wainwright and Bellwood 2002). Nexilosus latifrons shows similar pectoral fin morphology to Stegastes, although it lives in small groups, close to the rocks (Grove and Lavenberg 1997; Angel and Ojeda 2001). The paddling locomotion, performed in these taxa, is the one preferred motion for stopping, starting and yaw turning behavior, all maneuvers that require a strong powerful stroke (Walker and Weastneat 2002). Abudefduf concolor

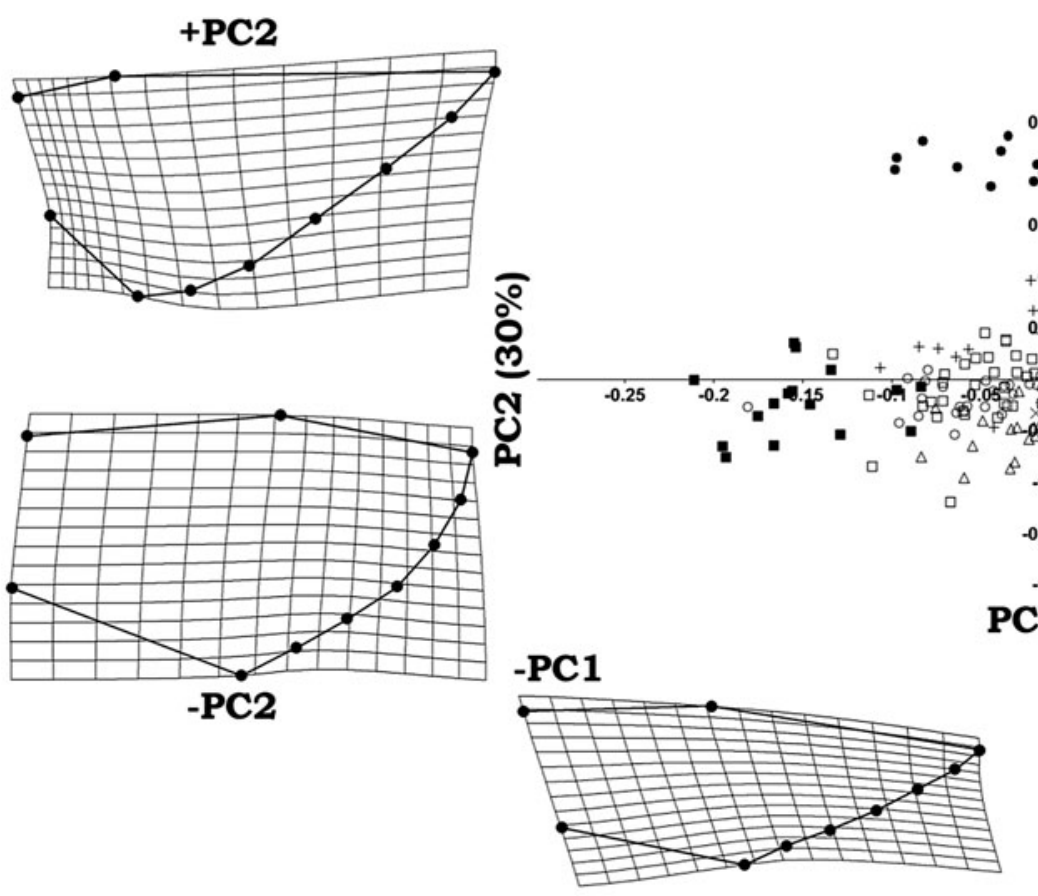

Fig. 7 Principal Components plot (PC1 vs. PC2) of the pectoral fin shape variation. Symbols refer to the seven genera and the outgroup. Cross: Abudefduf; black square: Azurina; white square: Chromis; $x$ :
Hypsypops; circle: Microspathodon; star: Nexilosus; white triangle: Stegastes; black circle: Z. rosaceus. Deformation grids indicate extreme shape along PC axes 


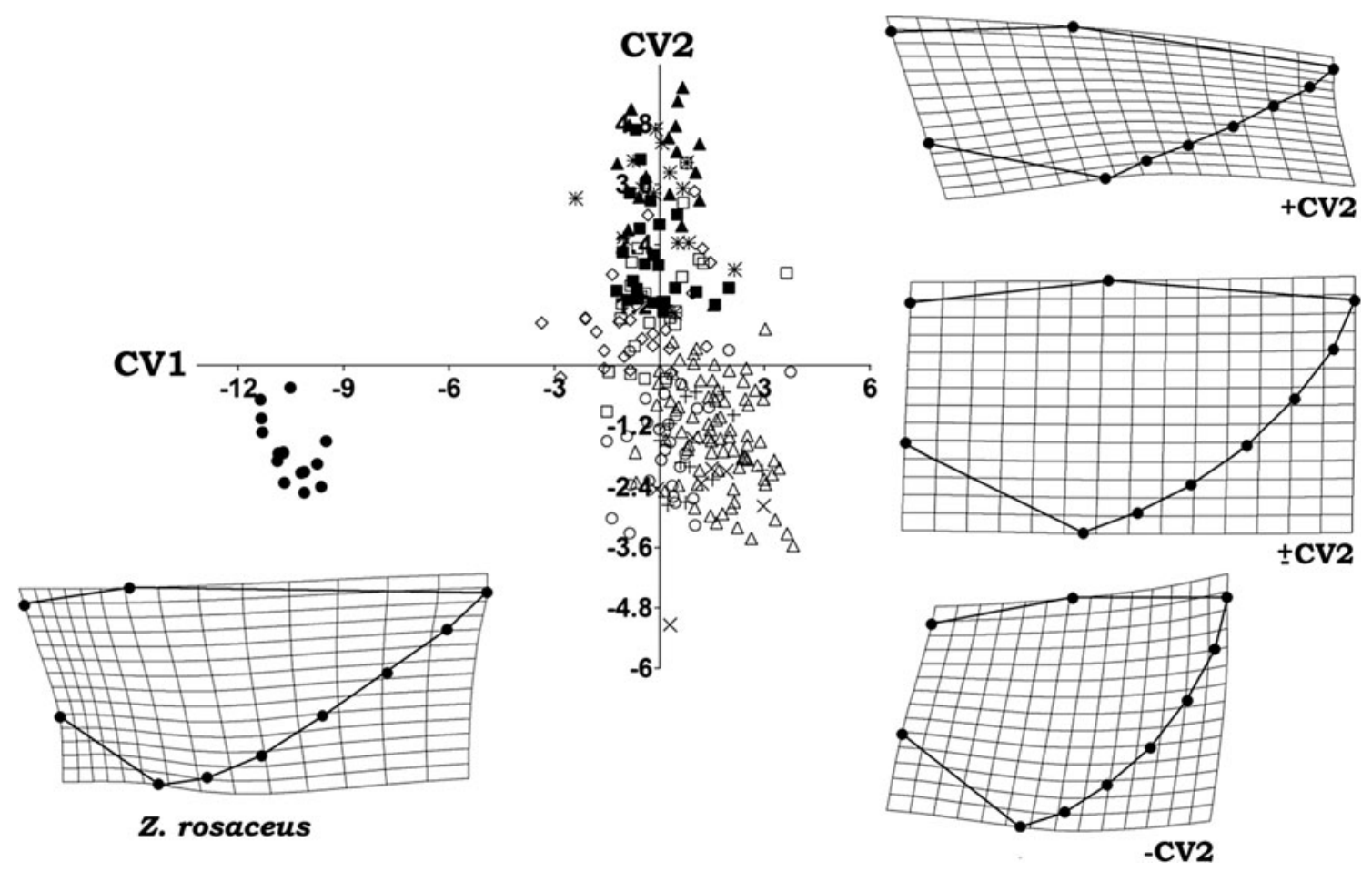

Fig. 8 Scatter plot of first two axis of a CVA of the pectoral fin shape using behavior as grouping factor. Symbols refer to behavioral groups (see Fig. 4). White triangle: Stegastes; cross: H. rubicundus; white circle: Microspathodon; X: N. latifrons; star: A. concolor and A. declivifrons; white square: C. alta, C. limbaughi and C. meridian;

and A. declivifrons show similar shapes to Stegastes, but the hydrodynamic leading and trailing edges are longer. Normally A. concolor and A. declivifrons are found close to the rocky beaches where the wave action is strong (Fig. 3). In order to negotiate the physical challenges of locomotion in such a wave-swept habitat, the pectoral fin of these species presents a high base (LMs 1-2) and their down support is short (LMs 9-10) to gain strength, and a long tip (LMs 2-3) to move fast.

Among territorial species, Microspathodon shows highly specialized pectoral fins (morphological group 2; Fig. 9). It has a long hydrodynamic leading edge, as free swimmers and a strongly curved hydrodynamic trailing edge, as territorial damselfishes. The behavioral pattern of Microspathodon seems to have strongly affected the morphological configuration of pectoral fins. Since this taxon is territorial, but can be found swimming away from its territory, their morphology combines patterns of both territorial and free swimmers.

Chromis and A. troschelii have pectoral fins designed from wing to paddle shapes (morphological group 3; Fig. 9). Generally speaking, the hydrodynamic leading edge is long and almost straight, and the hydrodynamic trailing edge is a little rounded. All these species are white diamond: C. crusma, C. intercrusma, and C. punctipinnis; black circle: Z. rosaceus; black triangle: Azurina; black square: A. troschelii and $C$. atrilobata. Deformation grids indicate extreme shape along $\mathrm{CV}$ axes

commonly found in the water column during the day forming groups feeding on zooplankton. The behavioral variation of these species is related to group size and position in the water column. Species forming big groups and swimming normally in the upper-medium part of the water column have lengthened pectoral fins (e.g., A. troschelii, C. atrilobata), which is important in order to swim fast around the reefs. Conversely, species forming small groups are normally found swimming close to the bottom (e.g., C. alta, C. limbaughi) presented wider and more powerful pectoral fins, which favor precise movements and strength allowing them to stay close to the reef bottom. The presence of intermediate morphologies may indicate the phylogenetic constraints or the fact that many fish may adjust their position along the rowing-to-flapping continuum (Wainwright et al. 2002).

Azurina, swimming actively in open water, show wingshape pectoral fin characterized by an angular tip, high AR and long leading edge (morphological group 4; Fig. 9). The basis of the fin is more rounded than in $Z$. rosaceus. According to Wainwright et al. (2002), this fin design should allow the best swimming performance for velocity, swimming long distance and escaping from predators, essential trait for this functional group. Such pectoral fin 


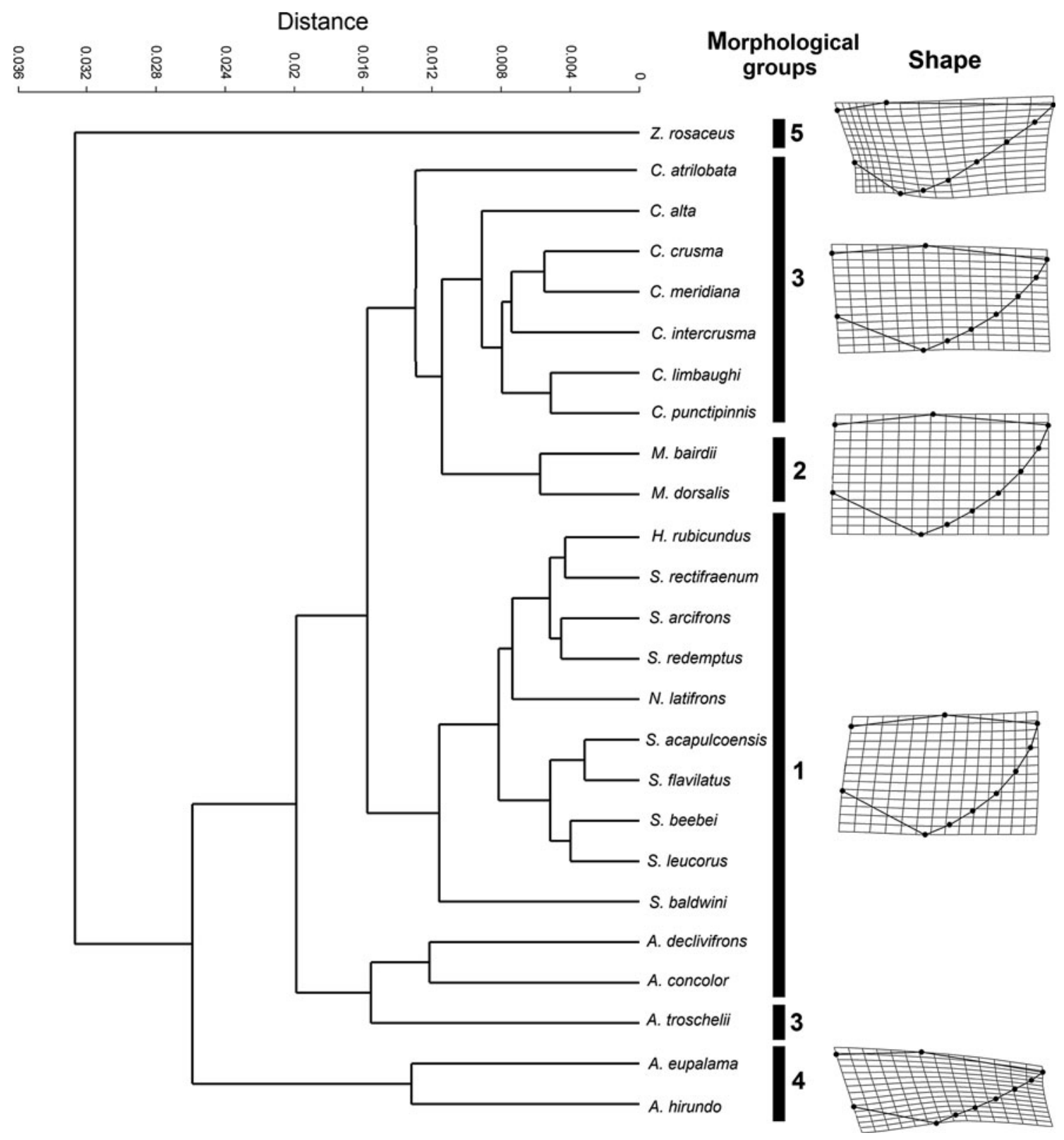

Fig. 9 Phenogram of morphological data (RWs), using Mahalanobis distance. Index of copheneric correlation: 0.861. Right: eco-morphological groups (See table 3). Deformation grids indicated the shape of each eco-morphological group

design was found in fishes swimming in more energetic zones on the reef (Fulton et al. 2001; Bellwood and Wainwright 2001).

Zalembius rosaceus can be found near the coast around rocky corals or sandy bottoms and in depths from 10 to $230 \mathrm{~m}$ (morphological group 5; Fig. 9). Zalembius rosaceus presents wing-shape pectoral fins which are slender, more angular and having a longer hydrodynamic leading edge than Azurina. This pectoral fin is typical of highperformance swimmers, which use flight swim mechanisms (Weastneat and Walker 1997).
Our results suggest that, even though traditional morphometrics give important information about the functional morphology of pectoral fin, the use of only this kind of characters may not extract all information of shape. Geometric morphometrics allow a more thorough analysis of pectoral fin shape variation. In this particular case, the use of semilandmarks allowed for detection of an important axis of variation of the pectoral fin: the curvature of the hydrodynamic trailing edge. For example, the use of this methodology highlights the association between territorial behaviors with a highly curved hydrodynamic trailing edge 
while non-territorial species are associated with a smooth hydrodynamic trailing edge.

\section{Evolutionary considerations}

According to Drucker and Lauder (2002), a high angle of fin attachment could be considered as a derivate character in ray-finned fishes. This pattern is observed between Pomacentridae and Embiotocidae. Zalembius rosaceus have a lower mean AFA value $\left(44^{\circ}\right)$ than pomacentrids of the Eastern Pacific $\left(\right.$ mean $=69^{\circ} ; \max =81.1^{\circ}$; $\min =$ $57.3^{\circ}$ ).

The molecular phylogeny of Quenouille et al. (2004) illustrated three clades within the genus Abudefduf. Abudefduf species living in the Eastern Pacific are segregated into two of these clades (1) A. troschelii and (2) A. concolor and A. declivifrons. This pattern was clearly recovered by behavioral and morphological data (present study; Aguilar-Medrano et al. 2011).

Geometric morphometrics did not reveal extensive pectoral fin shape variation among Chromis as expected by the diversity of behavior observed in this genus. However, the morphological data grouped $C$. atrilobata and C. punctipinnis as the extreme morphologies of Chromis. We observed differences between Chromis and Azurina suggesting that morphology, behavior and locomotion of Azurina are specific. Azurina could be considered as an extreme morphology of Chromis.

For almost all variables, Stegastes was found to be more closely related to Microspathodon,H. rubicundus and $N$. latifrons. Nexilosus latifrons and H. rubicundus have similar pectoral fin shapes, but behavioral data indicated a higher similarity level between Microspathodon and H. rubicundus.Stegastes showed a mean morphology ( $\mathrm{AFA}=77^{\circ} ; \mathrm{AR}=2.28$, while $H$. rubicundus presents the highest values of AFA $\left(80^{\circ}\right)$ and the lowest of the AR (2.17), while Microspathodon had the lowest values of AFA $\left(63^{\circ}\right)$ and the highest AR (2.59).

From a phylogenetic point of view (Tang 2001; Tang et al. 2003; Quenouille et al. 2004; Cooper et al. 2009), Microspathodon and Azurina can be thought of as derivate taxa from Stegastes and Chromis respectively. Microspathodon is territorial with lower AFA and higher AR than Stegastes, and Azurina is a free swimmer with lower AFA and higher AR than Chromis. The morphological and behavioral variations of these species apparently allowed for the division of ecological space thereby reducing the level of competition. The morphology of Microspathodon and Azurina is considered as extremes along the axis of the pectoral fin shape variation within damselfishes, and similar pattern of variation could be found within closely related genus. For example, within the genus Chromis, C. atrilobata shows similar values to Azurina, and within
Stegastes, S. baldwini and S. beebei have similar values to those of Microspathodon. According to this continuum of morphology, it can be hypothesized that the adaptive radiation of this family was gradual.

Diversity of pectoral fin morphology in coral reef fishes

The pattern of correlation between AFA and AR is similar between Pomacentridae and Labridae (present study, Wainwright et al. 2002): species with low AFA generally present high AR, and they are generally found in the water column, while species with high AFA present low AR are generally found feeding close to the reef (Fig. 6). The range of AR in damselfishes and labrids is similar (damselfishes $1.53-4.44 ; \quad \mu=2.61$; labrids $1.12-4.48$; $\mu=2.81$ ), but the range of AFA is higher in damselfishes $\left(50.8^{\circ}\right.$ to $\left.87.5^{\circ} ; \mu=70.2^{\circ}\right)$ than in labrids $\left(22^{\circ}-67^{\circ}\right.$; $\mu=47.54^{\circ}$ ). The Labridae group a lot of species that cover relatively long distances during their daily activities such as Thalassoma (Wainwright et al. 2002) and many of them inhabit the frontier between sandy and rocky or coral habitats. A low AFA favor the flapping motion that permits high speeds in the majority of labrid fishes. On the other hand, a high AFA favors front-back movements with high precision in damselfishes. The evolution of territoriality related to farming behavior could explain why the range of AFA observed in damselfishes is higher than in labrids. These traits may explain why damselfishes acquired different niches than labrids during their adaptive evolution. Labrids have been effective in developing morphologies specialized for swimming long distances, whereas damselfishes developed morphologies allowing for great maneuverability.

In conclusion, the variation of pectoral fin shape in damselfishes is highly related to behavior. The studies dealing with pectoral fin shape variation are limited but should be considered of great importance in determining patterns of adaptation in reef fishes and probably other fish communities. The study case of Pomacentridae shows that the pectoral fin shape may be a key morphological trait related to the adaptive success of fishes in various environments.

Acknowledgments We thank the Consejo Nacional de Ciencia y Tecnología (CONACYT, México) for a doctoral scholarship support to RAM to develop this work. Thanks to Lucia Campos Dávila (CIBNOR), Sandra J. Raredon (USNM), H.J. Walkers (SIO), Philip A. Hastings (SIO), Victor Cota Gómez (CICIMAR), José De La Cruz Agüero (CICIMAR) and Rick Feeney (LACM) for their help in the museum collections. Thanks also to Ismael Mascareñas Osorio, Fernando Aranceta Garza, Rafael Cabral, Juan J. Ramírez Rosas, Mario Cota Castro and Enrique Calvillo, all from CIBNOR, and Deivis S. Palacios from CICIMAR, for their enthusiastic assistance in the field trips. This work was supported in part by the Centro de Investigaciones Biológicas del Noroeste, México (projects EP2 and EP3), 
the National Commission for the Knowledge and Use of Biodiversity of México (CONABIO/CT001), National Council of Science and Technology of México (CONACYT/83339) and Secretary of Environment and Natural Resources (SEMARNAT-CONACYT/023390). Finally, we thank Michel Laurin for his enlightening comments. Bruno Frédérich is a Postdoctoral Researcher at the F.R.S.-FNRS (Belgium).

\section{References}

Adams DC, Rohlf FJ, Slice DE (2004) Geometric morphometrics: ten years of progress following the revolution. Ital J Zool 71:5-16

Aguilar-Medrano R, Frédérich B, De Luna E, Balart EF (2011) Patterns of morphological evolution of the cephalic region in damselfishes (Perciformes, Pomacentridae) of the Eastern Pacific. Biol J Linn Soc 102:593-613

Allen GR (1975) Damselfishes of the south seas. T.F.H. Publications, Neptune City

Allen GR (1991) Damselfishes of the world. Aquariums Systems, Mentor

Allen GR, Woods LP (1980) A review of the damselfish genus Stegastes from the Eastern Pacific with description of a new species. Rec West Aust Mus 8:171-198

Angel A, Ojeda FP (2001) Structure and trophic organization of subtidal fish assemblages on the northern Chilean coast: the effect of habitat complexity. Mar Ecol Prog Ser 217:81-91

Bellwood DR, Wainwright PC (2001) Locomotion in labrid fishes: implication for habitat use and cross-shelf biogeography on the Great Barrier Reef. Coral Reefs 20:139-150

Blake RW (1981) Influence of pectoral fin shape on thrust and drag in labriform locomotion. J Zool 194:53-66

Bookstein FL (1991) Morphometric tools for landmark datageometry and biology. University Press, Cambridge

Bray RN, Miller AC, Johnson S, Krause PR, Robertson DL, Westcott AM (1988) Ammonium excretion by macroinvertebrates and fishes on a subtidal rocky reef in southern California. Mar Biol 100:21-30

Cardini A, Elton S (2008) Does the skull carry a phylogenetic signal? Evolution and modularity and in the guenons. Biol J Linn Soc 93:813-834

Ceccarelli DM (2007) Modification of benthic communities by territorial damselfish: a multi-species comparison. Coral Reefs $26: 853-866$

Cooper JG (1863) On new genera and species of California fishes. Number I. Proc Cal Acad Nat Sci (1st Series) 3:70-77

Cooper WJ, Weastneat MW (2009) Form and function of damselfish skull: rapid and repeated evolution into a limited number of trophic niches. BMC Evol Biol 9:24

Cooper WJ, Smith LL, Weastneat MW (2009) Exploring the radiation of a diverse reef fish family: phylogenetics of the damselfishes (Pomacentridae), with new classifications based on molecular analyses of all genera. Mol Phyl Evol 52:1-16

Cuvier G, Valenciennes A (1833) Histoire naturelle des poisons. Paris: 9 FG Levrault

Dornburg A, Sidlauskas B, Santini F, Sorenson L, Near TJ, Alfaro ME (2011) The influence of an innovative locomotor strategy on the phenotypic diversification of triggerfish (Family: Balistidae). Evolution 65: no. doi:10.1111/j.1558-5646.2011.01275.x

Drucker EG, Lauder GV (2002) Wake dynamics and locomotor function in fishes: interpreting evolutionary patterns in pectoral fin design. Integr Comp Biol 42:997-1008

Emery AR (1973) Comparative ecology and functional osteology of fourteen species of damselfish (Pisces: Pomacentridae) at Alligator Reef, Florida Keys. Bull Mar Sci 23:649-770
Espinoza M, Salas E (2005) Estructura de las comunidades de peces de arrecife en las Islas Catalinas y Playa Ocotal, Pacífico Norte de Costa Rica. Rev Biol Trop 53(3-4):523-536

Evermann BW, Radcliffe L (1917) The fishes of the west coast of Peru and the Titicaca basin. Bull Unit Stat Nat Mus 95:1-166

Fowler HW (1944) Results of the Fifth George Vanderbilt expedition (1941) (Bahamas, Caribbean Sea, Panama, Galapagos Archipelago and Mexican Pacific Islands). The fishes. Mono Acad Nat Sci Phil 6:57-529

Frédérich B, Vandewalle P (2011) Bipartite life cycle of coral reef fishes promotes increasing shape disparity of the head skeleton during ontogeny: an example from damselfishes (Pomacentridae). BMC Evol Biol 11:82

Frédérich B, Pilet A, Parmentier E, Vandewalle P (2008) Comparative trophic morphology in eight species of damselfishes (Pomacentridae). J Morphol 269:175-188

Frédérich B, Fabri G, Lepoint G, Vandewalle P, Parmentier E (2009) Trophic niches of thirteen damselfishes (Pomacentridae) at the Grand Récif of Toliara, Madagascar. Ichtiol Res 56:10-17

Fulton CJ (2007) Swimming speed performance in coral reef fishes: field validations reveal distinct functional groups. Coral Reefs 26:217-228

Fulton CJ, Bellwood DR (2002) Ontogenetic habitat use in labrid fishes: an ecomorphological perspective. Mar Ecol Progr Ser 266:135-142

Fulton CJ, Bellwood DR, Wainwright PC (2001) The relationship between swimming ability and habitat use in wrasses (family Labridae). Mar Biol 139:25-33

Fulton CJ, Bellwood DR, Wainwright PC (2005) Wave energy and swimming performance shape coral reef fish assemblages. Proc R Soc Lond Ser B 272:827-832

Gilbert CH (1892) Scientific results of explorations by the U. S. Fish Commission steamer "Albatross." 22. Descriptions of thirty-four new species of fishes collected in 1888 and 1889, principally among the Santa Barbara Islands and in the Gulf of California. Proc Unit Stat Nat Mus 14:539-566

Gill TN (1862) Catalogue of the fishes of lower California in the Smithsonian Institution, collected by Mr. J. Xantus. Proc Acad Nat Sci Phil 14:140-151

Girard C (1854) Observations upon a collection of Fishes made on the Pacific coast of the United States, by Liut WP, Trowbridge USA, for the Museum of the Smithsonian Institution. Proc Acad Nat Sci Phil 7:142-156

Gluckmann I, Vandewalle P (1998) Morphofunctional analysis of the feeding apparatus in four Pomacentridae species: Dascyllus aruanus, Chromis retrofasciata, Chrysiptera biocellata and C. unimaculata. Ital J Zool 65:421-424

Greenfield DW, Woods LP (1980) Review of the deep-bodied species of Chromis (Pisces: Pomacentridae) from the Eastern Pacific, with descriptions of three new species. Copeia 1980:626-641

Grove JG, Lavenberg RJ (1997) The fishes of the Galapagos islands. Stanford University Press, California

Grove JS, Gerzon D, Saa MD, Strang C (1986) Distribución y ecología de la familia Pomacentridae (Pisces) en las Islas Galápagos. Rev Biol Trop 34(1):127-140

Hammer $\varnothing$, Harper DAT, Ryan PD (2001) PAST: palentological statistics software package for education and data analysis. Pal Elec 4(1):9

Heller E, Snodgrass RE (1903) Papers from the Hopkins Stanford Galapagos expedition, 1898-1899. XV. New fishes. Proc Wash Acad Sci 5:189-229

Hixon MA (1981) An experimental analysis of territoriality in the California reef fish Embiotoca jacksoni (Embiotocidae). Copeia 1981(3):653-665

Hobson ES (1965) Diurnal-nocturnal activity of some inshore fishes in the Gulf of California. Copeia 1965(3):291-302 
Hobson ES, Chess JR (1978) Trophic relationship among fishes and plankton in the lagoon at Enewetak Atoll, Marshall Islands. Fish Bull 76(1):133-153

Jordan DS, Evermann BW (1898) The fishes of North and Middle America: a descriptive catalogue of the species of fish-like vertebrates found in the waters of North America, north of the Isthmus of Panama. Part II. Bull Unit Stat Nat Mus 47:1241-2183

Jordan DS, Gilbert CH (1880) Description of a new flounder (Platysomatichthys stomias), from the coast of California. Proc Unit Sta Nat Mus 3:301-303

Klingenberg PC, Monteiro LR (2005) Distances and directions in multidimensional shape spaces: Implications for morphometric applications. Syst Biol 54(4):678-688

Lauder GV (2000) Function of the caudal fin during locomotion in fishes: kinematics, flow visualization, and evolutionary patterns. Am Zool 40:101-122

Lauder GV, Liem KF (1983) The evolution and interrelationships of the actinopterygian fishes. Bull Mus Comp Zool 150:95-197

Lauder GV, Nauen JC, Drucker EG (2002) Experimental hydrodynamics and evolution: function of median fins in rayfinned fishes. Integr Comp Biol 42:1009-1017

Lobel PS (1980) Herbivory by damselfishes and their role in coral reef community ecology. Bull Mar Sci 30:273-289

Mabuchi K, Miya M, Azuma Y, Nishida M (2007) Independent evolution of the specialized pharyngeal jaw apparatus in cichlid and labrid fishes. BMC Evol Biol 2007:7-10

Monteiro LR (1999) Multivariate regression models and geometric morphometrics: the search for causal factors in the analysis of shape. Syst Biol 48:192-199

Monteiro NM, Quinteira SM, Silva K, Vieira MN, Almada VC (2005) Diet preference reflects the ontogenetic shift in microhabitat use in Lipophrys pholis. J Fish Biol 67:102-113

Nichols JT (1924) A contribution to the ichthyology of the Galapagos. Zoologica 5:63-65

Núñez L, Vásquez J (1987) Observaciones tróficas y de distribución espacial de peces asociados a un bosque submareal de Lessonia trabeculata. Est Oceanol 6:79-85

Petersen CW, Marchetti K (1989) Filial cannibalism in the Cortez damselfish Stegastes rectifraenum. Evolution 43(1):58-168

Quenouille B, Bermingham E, Planes S (2004) Molecular systematics of the damselfishes (Teleostei: pomacentridae): bayesian phylogenetic analyses of mitochondrial and nuclear DNA sequences. Mol Phyl Evol 31:62-68

Robertson DR, Allen GR (2008) Shorefishes of the Tropical Eastern Pacific online information system. Version 1.0 Smithsonian Tropical Research Institute, Balboa, Panamá. www.neotropicalfishes. org/sftep, www.stri.org/sftep

Rohlf FJ (1993) Relative warps analysis and an example of its application to mosquito wings. Contributions to Morphometrics.
In: Marcus LF, Bello E, Garcia-Valdecasas A (eds) Monografías del Museo Nacional de Ciencias Naturales, CSIC. Madrid, pp 139-151

Rohlf FJ (1999) Shape statistics: procrustes superimpositions and tangent spaces. J Class 16:197-223

Rohlf FJ, Marcus LF (1993) A revolution in morphometrics. Trends Ecol Evol 8(4):129-132

Rohlf FJ, Slice D (1990) Extension of the procrustes method for the optimal superposition of landmarks. Syst Zool 39:40-59

Rothans TC, Miller AC (1991) A link between biologically imported particulate organic nutrients and the detritus food web in reef communities. Mar Biol 110:145-150

Sfakiotakis M, Lane DM, Davies JBC (1999) Review of fish swimming modes for aquatic locomotion. IEEE J Ocean Eng 24(2):237-252

Streelman JT, Karl SA (1997) Reconstructing labroid evolution using simple-copy nuclear DNA. Procc Roy Soc B: Biol Sci 264: $1011-1020$

Tang KL (2001) Phylogenetic relationships among damselfishes (Teleostei:Pomacentridae) as determined by mitochondrial DNA data. Copeia 2001(3):591-601

Tang KL, MacNyset KM, Holcroft NI (2003) The phylogenetic position of five genera (Acanthochromis, Azurina, Chrysiptera, Dichistodus, and Neopomacentrus) of damselfishes (Perciformes: Pomacentridae). Mol Phyl Evol 30:823-828

Tschudi JJ (1846) Ichthyologie. Pp. ii-xxx + 1-35 Pls 1-6 In: Untersuchungen über die Fauna Peruana. Scheitlin and Zollikofer 1-693

Wainwright PC, Bellwood DR (2002) Ecomorphology of feeding in coral reef fishes. In: Sale, PF (eds) Coral reef fishes, dynamics and diversity in a complex ecosystem. Elseviere Sciences, California, pp 33-55

Wainwright PC, Bellwood DR, Weastneat MW (2002) Ecomorphology of locomotion in labrid fishes. Environ Biol Fish 65:47-62

Walker JA (2004) Dynamics of pectoral fin rowing in a fish with an extreme rowing stroke: the threespine stickleback (Gasterosteus aculeatus). J Exp Biol 207:1925-1939

Walker JA, Weastneat MW (2002) Performance limits of labriform propulsion and correlates with fin shape and motion. J Exp Biol 205:177-187

Weastneat MW, Walker JA (1997) Applied aspects of mechanical design, behavior, and performance of pectoral fin swimming in fishes. Proc Unma Unte Sub Tech 1997:1-14

Webb PW (1982) Locomotor patterns in the evolution of actinopterygian fishes. Am Zool 22:329-342

Webb PW (2002) Control of posture, depth, and swimming trajectories of fishes. Integr Comp Biol 42:94-101

Zelditch ML, Swiderski DL, Sheets HD, Fink WL (2004) Geometric morphometrics for biologists: a primer. Elsevier Academic Press, London 